Book review

\title{
Review of Lucia Abbamonte. 2018. Black Lives Matter. Newcastle, Cambridge Scholars Publishing. ISBN 978-1527506572
}

\author{
Douglas Mark PONTON \\ University of Catania \\ Catania, Italy
}

For citation:

Ponton, Douglas Mark. 2021. Review of Lucia Abbamonte. 2018. Black Lives Matter. Newcastle: Cambridge Scholars Publishing. Russian Journal of Linguistics 25 (2). 569-574. DOI: https://doi.org/10.22363/2687-0088-2021-25-2-569-574

Рецензия

\section{Рецензия на книгу \\ Lucia Abbamonte. 2018. Black Lives Matter. Newcastle, Cambridge Scholars Publishing. ISBN 978-1527506572}

\author{
Дуглас Марк ПОНТОН \\ Катанийский университет \\ Катания, Италия
}

\section{Для цитирования:}

Ponton D. M. Review of Lucia Abbamonte. 2018. Black Lives Matter. Newcastle: Cambridge Scholars Publishing. Russian Journal of Linguistics. 2021. T. 25. № 2. C. 569-574. DOI: https://doi.org/10.22363/2687-0088-2021-25-2-569-574

Critical Discourse Analysis (CDA) has represented an important branch of mainstream linguistics for almost half a century. It arguably owes its origins to movements in modern French philosophy (e.g. Foucault 1963, Barthes 1973), and emerged at University of East Anglia (UEA) in the late 1970s, in the work of a politically committed group of scholars (Fowler et al 1979, Fowler 1991). Analysts explore the links between patterns of linguistic or semiotic representation and the social structures that come into being as a result of these. Importantly, CDA provides us with tools to de-construct discourse, to expose how specific harmful or exploitative forms of language, thought and behaviour have become 'naturalised' 
(Barthes, ibid); that is, they appear not to depend on human agency but to be just 'the way things are'. These studies have dealt with a broad range of topics, including political themes (Fairclough and Wodak 1997, Fairclough 2000, Larina et al 2019, etc.), social topics such as racism (Van Dijk et al 1997), environmentalism (Stibbe 2015), and so on.

The long-term aim of such studies, naturally, is to effect social change. Such is also the aim of a recent offshoot of CDA, 'positive discourse analysis' (Martin 2004), which shares many of the key tenets of the earlier school, but rather focuses on discursive practices that work, that construe or describe positive situations and the linguistic structures on which they depend.

In this context, Abbamonte's book emerges as an exemplary publication, focusing on the theme of anti-black racism in the US and drawing on the methodologies of both analytical schools to make its point (see also Chilton 2004). The appearance of the book, indeed, could hardly be more timely, as recent events in America confirm; events it anticipates by focusing on the same phenomena occurring at a slightly earlier period. Though the election of Barack Obama as America's first black president in 2009 was widely seen, at the time, as an indication of more tolerant social attitudes, Abbamonte discusses several flashpoints that occurred during his tenure, and of course, the issues have only become more pressing under Trump. It is indeed ironic, as the author notes, that Obama's election, hailed at the time as a transformative breakthrough for the Civil Rights movement of the 1960s, should have resulted instead in two steps back in other areas of American society, including policing and neighbourhood securitisation.

Since the book was written, the Black Lives Matter movement has taken giant steps to bring anti-black racism before popular consciousness. Sportsmen of all colours now regularly 'take the knee' before matches. Works such as this, that explore the role of language in construing racial hatred and its opposites and expose underlying habits of thought and behaviour, are also important in bringing about change.

In the foreword, Abbamonte lays out her motivation for writing the book, as well as indicating some underlying themes that will resurface in later chapters. The book views anti-black racism in America as the institutionalisation of wider social attitudes which may be traced, naturally enough, to the country's well-known history in this area. However, the impact of news media, and also the burgeoning popular reliance on social media for facts and opinions, are the focus of the linguistic work. A key perspective, in fact, is the notion that mainstream media are only responsible for part of the phenomena by means of which hostile racial stereotypes circulate in memetic fashion, to perpetuate scenarios of injustice, and the increasingly powerful voice of the black protest is heard. The rest, and arguably the greater part of the process, is carried out by tweets, re-tweets, facebook posts, instagram and so on, a jungle telegraph that constructs communities of ideas, responding instantly to ongoing events, influencing attitudes at a global level. As Abbamonte notes in her discussion of the Trayvon Martin case, multi-media and 
cross-media communication mean that such cases are tried in the court of public opinion. Whatever the official outcome, the social spin-off will be a hardening of opposing attitudes, and a confirmation of prejudices, that result from the rapid exchanges of opinion about the case through informal media sources.

The author takes a position against the US government bureaucracy on these issues, pointing out, for example, that it keeps records of such comparatively trivial matters as wild animal attacks, but not statistics for the killing of black citizens by police. As she states the matter:

"a general audience of American and international readers increasingly shares concerns about the use of deadly force by police" (p. 1).

It has been left, as she says, to the British newspaper 'the Guardian', to compile a list, 'the Counted' recording these fatalities, rescuing such cases from their official oblivion. The US police do, however, report 'justifiable homicides' to the FBI, with a yearly average of some 400 cases involving blacks. Though serious in itself, this is by no means a comprehensive figure; the total number, says Abbamonte, is likely to be 'staggering'.

Another social feature that receives critical attention, especially in the Trayvon Martin chapter, are America's gun laws, seen as contributing to a disturbed climate where confrontations easily escalate and lead to tragic outcomes.

The book's aim is to use a variety of complementary linguistic tools and approaches to shed light on the link between patterns of representation and patterns of thought. It is organised as follows:

Chapter One focuses on the difficulties involved in finding reliable data, the media's role in data gathering, thus underlining, at the outset, the fundamental role of media in these processes. Some of the cases that are presented show the same patterns of police behaviour found in the recent George Floyd killing, evidence of a persistent pattern of racial profiling. An Amnesty International spokesman claims that, in America "you're twice as likely to be shot if you're an unarmed black male" (p. 9).

Chapter Two presents the methodologies used, beginning with a useful summary of the aims and methods of Critical Discourse Analysis, the paradigm within which the book is situated. The main analytical tools are those developed by followers of the Hallidayan school, James Martin and Peter White, among others. The author provides a refreshing overview of CDA that stresses its debts to French traditions, emphasising, alongside other important names, the work of Roland Barthes and Michel Foucault. In adopting a multimodal approach, the text further underlines these connections, and Abbamonte has a nice phrase, 'the infringement of images on words', to capture the blending of image and word that typifies our current semiosphere. These approaches are convincingly integrated with Van Leeuwen's theorisation of the representation of social actors, originally conceived of in terms of textual representations, but here usefully extended to cover images.

Chapter Three deals with the 2012 shooting of Trayvon Martin, an event which spurred the foundation of the Black Lives Matter movement. In accordance with 
the principles of Ruth Wodak's Discourse Historical Approach, the chapter lays out the socio-historical details with reference to authentic textual/visual artefacts; eyewitness accounts, social media responses, newspaper articles and photos, media products such as news broadcasts, and so on. The text of the 'Stand Your Ground' statute is quoted at length, in order to explicate its role in the trial. The chapter also features a full-scale analysis of a corpus of newspaper texts using the Appraisal Framework, the Hallidayan tool for assessing speaker evaluation. A thick sociolinguistic picture emerges, that effectively captures a single historical moment and conveys something of its national and global resonance. This chapter also includes a nuanced discussion of the response to events of US president, Barack Obama, attempting to bridge the racial divide, his personal history throwing the issues into sharp relief.

Chapter Four uses the same approaches with regard to Michael Brown, the 'model student' who was shot by police when unarmed, in 2014. It begins with a quote from Obama's biography, recalling his own sense as an adolescent that 'something wasn't quite right' with America's race relations, despite the country's apparently egalitarian social structures. In this incident, as in many others, the notguilty verdicts handed down to the officer involved in the shooting sparked riots which resulted in further violence. Abbamonte underlines here the role of social media in spreading outrage at the killing and the verdict, and gives instances of celebrity involvement that show the social impact of such dissemination.

Chapter Five presents the final case study, the 2015 Emanuel Church massacre, which involved the cold-blooded shooting of nine members of a congregation by a white supremacist, Dyllan Roof. Abbamonte situates these events in a context that is not limited to the USA but rather emphasises their worldwide relevance, as in the following reflections:

His (Roofe's) words, images, photos had a space in the worldwide web - and not a unique, isolated space. The advantages of easy, real-time communication across media and cultures cannot easily be overvalued (p. 180).

As with the other chapters, the events are brought close through period photos and in-depth coverage of the salient facts and background issues.

Chapter Six moves towards a conclusion, and discusses current social movements, their indebtedness to the affordances of new media, and the centrality of discourse in promoting social change.

In the latter part of the book, Abbamonte's own political engagement and emotional involvement with these tragic issues, which may be felt throughout, emerge with greater clarity. This is a work which, like many CDA inspired studies, takes a definite side - i.e., against racism and racists and those who object to the thesis that Black Lives Matter - and for the victims of these modern atrocities.

The focus shifts somewhat towards the role of different forms of media, their stances, their strategies and their power to affect social change. It discusses the role of language, its centrality to Afro-American culture and its hidden potentialities that may hold hope for the future. 
In fact, the book concludes on a positive note, aligning itself with the emerging paradigm of 'positive discourse analysis', and looking forward to a 'post-racial era', stressing the role of the English language in producing 'new transformative meanings'. It deserves a wide readership, both for its scholarly qualities, which include the incisive application of a broad range of analytical tools, and for the importance and topicality of its theme.

(C) Douglas Mark Ponton, 2021
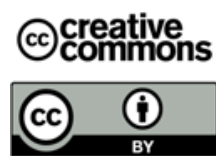

This work is licensed under a Creative Commons Attribution 4.0 International License https://creativecommons.org/licenses/by/4.0/

\section{REFERENCES}

Barthes, Roland. 1973. Mythologies. Lavers, A. (trans.). London: Paladin.

Chilton, Paul. 2004. Analyzing Political Discourse: Theory and Practise. London and New York: Routledge.

Schäffner, Christina (ed). 1997. Analysing Political Speeches. Multilingual Matters: Clevedon. Fairclough, Norman. 2000. New Labour, New Language. London: Routledge.

Fairclough, Norman \& Ruth Wodak. 1997. Critical discourse analysis. In Van Dijk, Teun (ed.). Discourse Studies: A Multi-Disciplinary Introduction. Vol. I. Discourse as Structure and Process. London: Sage.

Foucault, Michel. 1963. Naissance de la clinique: une archeologie du regard medical. Paris: Presses Universitaires de France.

Fowler, Roger. 1991. Language in the News. London: Routledge.

Fowler, Roger, Bob Hodge, Gunther Kress \& Tony Trew. 1979. Language and Control. London: Routledge.

Larina, Tatiana, Vladimir Ozyumenko \& Douglas Ponton. 2019. Persuasion strategies in media discourse about Russia: Linguistic ambiguity and uncertainty. Lodz Papers in Pragmatics 15 (1). 3-22. DOI: https://doi.org/10.1515/lpp-2019-0002

Martin, James. 2004. Positive discourse analysis: Solidarity and change. Revista Canaria de Estudios Ingleses 49. 179-200.

Stibbe, Arran. 2015. Ecolinguistics: Language, Ecology and the stories We Live by. New York: Routledge.

Van Dijk, Teun, Stella Ting-Toomey, Geneva Smitherman \& Denise Troutman. 1997. Discourse, ethnicity, culture and racism. In Van Dijk, Teun (ed.). Discourse Studies: A Multidisciplinary Introduction. Vol. 2: Discourse as social interaction. London: Sage.

\section{Book review history:}

Received: 4 November 2021

Accepted: 21 March 2021

\section{История рецензии:}

Дата поступления в редакцию: 4 ноября 2020

Дата принятия к печати: 21 марта 2021 


\section{Bionote:}

Douglas Mark PONTON is Associate Professor of English Language and Translation at the Department of Political and Social Sciences, University of Catania. His research interests include political discourse analysis, ecolinguistics, sociolinguistics, applied linguistics, pragmatics and critical discourse studies. Recent publications include "For Arguments Sake: Speaker Evaluation in Modern Political Discourse" and "Understanding Political Persuasion: Linguistic and Rhetorical Aspects". As well as politics, his research deals with a variety of social topics including tourism, the discourse of mediation, ecology, local dialect and folk traditions, including proverbs and the Blues.

\section{Contact information:}

Dipartimento di Scienze Politiche e Sociali

University of Catania

Via Vittorio Emanuele II 49

Catania, 95131, Italy

e-mail:dmponton@gmail.com

ORCID: 0000-0002-9968-1162

\section{Сведения об авторе:}

Дуглас Марк ПОНТОН - доцент, преподаватель английского языка и перевода на кафедре политических и социальных наук в Катанийском университете (Италия). Сфера его научных интересов включает анализ политического дискурса, эколингвистику, социолингвистику, прикладную лингвистику, прагматику и критический дискурс-анализ. Его новейшие публикации: "For Arguments Sake: Speaker Evaluation in Modern Political Discourse” («Во имя аргументов: оценка оратора в современном политическом дискурсе») и "Understanding Political Persuasion: Linguistic and Rhetorical Aspects” («Способы убеждения в политике: лингвистические и риторические аспекты»). Наряду с политикой интересы Д.М. Понтона связаны с социальной тематикой: туризмом, дискурсом медиации, экологией, местными диалектами, народными традициями, пословицами и блюзом.

\section{Контактная информация:}

Dipartimento di Scienze Politiche e Sociali

University of Catania

Via Vittorio Emanuele II 49

Catania, 95131, Italy

e-mail:dmponton@gmail.com

ORCID: 0000-0002-9968-1162 